\title{
Call for replacement for UGC and bigger role for industry
}

\section{London}

BRITISH industrialists and women must play a greater part in influencing the education and research needs of the nation while government, via a special commission, should have immediately available expert counsel on education.

These recommendations have emerged from a committee created to review the University Grants Committee (UGC) the principal financial watchdog of higher education. The committee, chaired by Lord Croham, chairman of the bankers Guinness Peat and former head of the Home Civil Service, concludes that "national needs" are being ignored by the educational establishment and that a more "open" approach is needed to ensure that those demands are satisfied.

The UGC should be replaced by a council with no more than 15 members, says the committee's report, while a newly created UK Education Commission would provide advice on the educational needs of industry and commerce.

The new bodies would have a membership that reflects national interests. The committee was emphatic that industry and commerce "Do not at present have a satisfactory focus for the expression of their views and on that account were not playing as full a part as they might in national debate on education".

The UGC, established in 1919, currently has 17 members but more than a dozen sub-committees. The proposed council would be steered principally through the new office of a director general, a full-time member who would preside in the chairman's absence. The profile of that chairman must also change. He or she must be "An eminent person from outside the academic world".

The constitution of the council would be changed dramatically with the membership no longer dominated by prominent academics. The UGC, presently chaired by Sir Peter Swinnerton-Dyer, has only one woman member - a fact that is singled out for criticism by Croham. A council dominated by men would be unlikely to explore how women could play a fuller role in universities, says the report.

While not overtly criticizing the present system, the nine members of the Croham committee conclude that "Through no fault of its present members, the UGC lacks the necessary balance of experience". The Croham report emphasized that the academic judgement frequently asked of the UGC should be conducted within the perspective of "public interest". There must be a wider economic and social perspective when addressing these questions.
The UK Education Committee which could either be assembled periodically or be in permanent session, would be responsible for advising the government "on national goals for the education service as a whole, and on any reforms which might be necessary". Both new bodies are to be assisted, if the recommendations gain approval, by triennial budgets established for the universities, assuming the annual inflation rate remains below five per cent.

The coordination of the management and funding of medical education also needs attention, says the Croham study. A sub-group led by Lord Butterworth, former vice-chancellor of Warwick University, specifically investigated the problems. The current machinery which depends on joint policies hatched by the Department of Education and Science, the Department of Health and Social Security, and the UGC is weak, says Croham, "with the result that too much is left to chance. That is a matter which needs urgently to be tackled by the departments concerned". Bill Johnstone

The Croham report is published at $£ 7.20$ as " $R e$ view of the University Grants Committee", Command 81 , HMSO.

\section{New technique to}

\section{gauge sea ice}

\section{London}

A NEW method, employing the characteristics of impulse radar, has been developed to measure the thickness of sea ice, allowing oil companies to determine easily the forces exerted by icefloes against structures such as oil or gas platforms.

The radar unit, developed jointly by Exxon Production Research Company and the British-based Cambridge Consultants, is mounted on a helicopter and emits short pulses of electromagnetic energy from antennas fitted on one side of the aircraft. The energy is in part reflected from the top of the ice and also from the interface between the bottom of the ice and the sea water. These reflections are collated by a receiving antenna housed at the other side of the helicopter.

The time difference between the received signals and the velocity of this radar energy as it travels in the ice allows the thickness to be easily determined. The device, which can accurately measure up to $30 \mathrm{ft}$ to within one foot, supersedes manual drilling techniques. According to the inventors of the impulse radar de' ice, "it is possible to collect more data in $\mathbf{3 0}$ minutes than can be obtained by a six-man crew drilling for two days". Bill Johnstone
All change at the top for India's Nuclear agenti

The crisis in India's Department of Atomic Energy (DAE; see Nature 325, 565; 1987) has deepened with the resignation of Dr P.K. Iyengar, director of the Bhabha Atomic Research Centre, the physicist credited with the design of the plutonium device that India exploded in 1974. His departure follows the announcement on 9 February of the appointment of his rival, Dr M.R. Srinivasan, head of the Nuclear Power Board, as successor to Dr Raja Ramanna, the retiring chairman of the Atomic Energy Commission (AEC).

Iyengar, who is 55, said he was seeking voluntary retirement after 32 years of service. Dr N. Srinivasan, a close associate of Iyengar, has also resigned from his post as director of heavy-water projects but for reasons, he says, unconnected with the controversy over who should be the new chairman of AEC.

The Prime Minister, Mr Rajiv Gandhi, who is also in charge of atomic energy, is upset over the row among senior scientists at a time when the threat of a Pakistani nuclear device is looming large and when India is launching an ambitious 15-year programme to expand nuclear power capacity from $1,000 \mathrm{MW}$ at present to $10,000 \mathrm{MW}$. In the wake of criticism in the media about the inept handling of the succession at AEC, Mr Gandhi personally intervened, but was unable to dissuade Iyengar from resigning.

The vertical structure of Indian scientific organizations and the immense power bestowed on their heads leads to intense competition for senior posts. The AEC chairman automatically becomes secretary to the government; he also draws the highest salary of any scientist.

M.R. Srinivasan, who will take over from Ramanna at AEC on 1 March, is a British-trained mechanical engineer. He joined DAE in 1955 and was in charge of its nuclear power projects division until, in 1984, this was reconstituted as the Nuclear Power Board, whose chairman he became. No successors to Iyengar and Srinivasan have yet been named.

In the meantime, Mr Gandhi has set up a committee under his science adviser, Professor M.G.K. Menon, to study the Soviet offer of two 440-MW light-water reactors. When the offer was made four years ago it was rejected by Ramanna and Iyengar because it did not fit the Indian nuclear programme. Following so soon after Mr Mikhail Gorbachev's visit to India, the prime minister's action is interpreted as a sign that India may now import the Soviet reactors.
K. S. Jayaraman 